\title{
TRANSLATION OF THE NOVEL BY CARLOS RUIZ ZAFÓN "SHADOW OF THE WIND" INTO RUSSIAN: THE SEMANTIC DIFFERENTIAL OF LEXICAL RELEVANCE
}

\author{
Ekaterina Zvereva
}

Associate Professor of Foreign Languages Department at Law Institute of RUDN University, Russia, zvereva ev@pfur.ru

\begin{abstract}
The translation should organize our perception around the translated book in the same way that the original organized the reader's perception around itself. One of the difficulties of translation is the transition from one language to another and from one culture to another. Therefore, the translator must have a good command of the two languages, the source, and the translator, and have in-depth extralinguistic knowledge to help the reader-recipient of the translation avoid the difficulties of misunderstanding that arise from socio-cultural differences. In translating a work of art, the language worldview of the author and the translator interact, resulting in a modified language worldview of the source text. The work of Carlos Ruiz Zafón can rightfully be considered the property of the Spanish-speaking world and a significant contribution to the world's literary treasury. His works undoubtedly sound like a unique voice in the multilingual chorus of world literature. Zafón's books are perceived as an invitation to an incredible journey.

It is almost impossible to define Zafón's genre as well as to put the book down. The idiostyle of Zafón is unique and is an alloy of various genres, and therefore, it is an exciting material for linguistic and literary analysis. In this article, we consider the novel "The Shadow of the Wind" as a manifestation of commitment to Gothic aesthetics, as a document of aesthetic self-expression. We are attempting to compare some selected fragments of the novel "Shadow of the Wind" and the versions of the novel's existing translations into Russian. The analysis is carried out based on the translation made by M. Smirnova and V. Temnov. The relevance is considered from the completeness of semantic nuances, the author's intentions, and original imagery, implicitly embedded in sign words and phraseological units. Such fruits of artistic fantasy, subjected to deliberate infantilization and stylized as adolescent perception, represent the most critical universal antitheses (light/darkness, harmony/ugliness, life/death). They are complemented by metaphorical motives of the mask, play, shadow, mirage, sleep. The main characteristic of his work is the dualism of images and plots and their intertextuality. Zafón's novel's main binomial is the dualism of the angel/demon. The well-founded artistic images-comparisons in the novels analyzed by us are saturated with significant sensory power expression.
\end{abstract}

Keywords: Zafón, neo-Gothic, contemporary Spanish literature, artistic picture of the world, motivation, translation adequacy, translation choice, internal word form, perception, impression, semantics.

\section{INTRODUCTION}

The modern world is going through a process of rethinking the contradictory reality and man's role in it, summing up the results of two millennia of civilization development. From the 20th century, we are 
witnessing a continuous process of convergence of world cultures. The scientific and technological revolution linked national economies together, creating a solid foundation for rapid interpenetration and merging of spiritual values formed within national cultures' framework. As a result, a public mass culture has been formed that does not require internal "spiritual work" from consumers. Modern youth culture has provided a counterbalance to it, as a uniquely creative way of asserting one's alternative position. The desire of a person to become a self-actualizing person can lead to individual or collective protest, which, in turn, can be expressed in the acceptance of the style and values of a particular subculture. Modern Spanish literature, a worthy and full-blooded heir to Spanish literature's philosophical tendencies in general, focuses on the individual as the center of the universe and the main object of knowledge. For Spanish literature, the individual's inner world and his relationship with the outside world are of the most significant interest as a creative material and source of inspiration. We can say that the hero's personality is, for Spanish authors, the leading creative "tool" that creates the entire artwork.

Literature is a writer's way of knowing the world and himself, connected with the specific feature of thinking in artistic images. Being fundamentally anthropocentric, creative consciousness tends to comprehend and depict a person.

Spanish novelism, stereotypically personified by Cervantes's personality, begins and ends with this remarkable artist-dreamer and visionary of the 16th century for most readers of the world. In the 21st century, the Spanish novel found itself on the periphery of the mass literary consciousness. Catalan author C. Ruiz Zafón became one of those authors who brought the reader back to the world of Spanish literature, having managed to melt realism and fantasy, crime detective and historicity, mysticism and romance into an innovative amalgam.

C. Ruiz Zafón is called the second most widely read Spanish writer in the world after M. Cervantes. The Catalan author's books have been translated into 50 languages and are in unprecedented demand worldwide. His novels are famous for their dark Gothic mood, twisted plot, and sarcastic humor. The success of $\mathrm{C}$. Ruiz Zafón is explained by the fact that he was able to perceive the popular literary techniques of his predecessors, subtly feel the needs and specifics of the tastes of young people, as well as the conjuncture of the fiction market.

Viral was his program novel "Shadow of the Wind," which was the first in the tetralogy "Cemetery of forgotten books." This work was published in Russian in 2007. We decided to analyze some fragments of its translation into Russian, made by a creative Duo of literary critic M. B. Smirnova and professor, member of the Union of Writers of Russia V. Mikhailin, who performs under the pseudonym "Vasily Temnov" and specializes mainly in translations from English and German. We are interested in how much the Russian version managed to preserve the connotations and contextual semantics of lexical and phraseological units, the depth of imagery, and the metaphor of the author's artistic picture of the world.

\section{THEORETICAL BACKGROUND OF THE ISSUE ANDER STUDY}

The Spanish neo-Gothic novel is an original didactic resource in the Humanities, genetically going back to the romanticism of Shelley and Goethe, feeding on the energy of magical realism that emerged in Latin America in the 20 s of the last century as the apotheosis of a century-long overcoming of alienation from the original culture of indigenous peoples (llina, 2016). Initially, in some countries, the conquistadors' descendants went by referring to the myths of Indian civilizations, while in others, they resorted to "literary myth-making" (Larikova, 2018. p. 239). Thus, the fantastic world of C. Ruiz Zafón owes much to the symbolism of iconic images of world literature of the XIX-XX centuries, covering both the Old and New World.

As for the problems of literary translation from the point of view of comparative literature studies, it should be noted that translation can be "compared with the original - and other translations into the same language, and translations into other languages - as typologically similar phenomena, and the differences between them can be understood in their objective conditionality by language features, environment, time, readers' perception, literary traditions, and, of course, - the translator's personality, the "creative lens" through which the work of art of the word inevitably breaks, appears in a new guise" (Toper, 2001. p. 219).

On the other hand, "the introduction of the problems of literary (artistic) translation into the system of comparative literary studies allows us to consider the functioning of translated works in a foreign language environment as newly created artistic values" (Toper, 2001. p.186). According to A. Sadokhin, it is in the language that the picture of the world "is realized, verbalized, stored and transmitted from generation to generation. In this process, words are not just names of objects and phenomena, but a piece of reality passed through the prism of the cultural picture of the world and therefore acquired specific features inherent 
in this people" (Sadokhin, 2014. p. 101). In a literary text, a language personality is recognized as the author's language personality with the specifics of his language picture of the world and the dictionary as the basis of this picture. The writer's artistic world is formed with the help of individual author's artistic concepts, which allows us to talk about an" individual author's picture of the world", which includes "the arsenal of language tools that the author uses to describe the world " (Pimenova, 2014. p. 91). The individual author's picture of the world is reflected in the text. It is exceptionally subjective and has the features of its creator's linguistic personality, which "is due to the aesthetic nature of the reflection of reality and the text's anthropocentrism. A productive way to describe an individual author's picture of the world is conceptual analysis, which consists in deducing from the content of the entire text the basic concept, as well as information and knowledge about the concept that makes up its concept sphere" (Babenko, 2005, p. 341).

In our opinion, adequate perception of a literary text is impossible without the possession of a specific volume of the cultural fund, since it is on the knowledge of the cultural fund that the author of a literary text builds his communication with the reader. Comparing the author's creative activity of a work of art with the activity of a translator, I. Kashkin showed the dependence of the second on the first: "the writer is free to choose the boundaries of his imagination. He can write a scientific, historical novel or utopia, not a lyrical confession. Moreover, the material for it is the whole world. The translator is limited in choice: the translator's world is closed within the pages of the original, it is a world already reflected in the author's mirror" (Kashkin, 1977. p. 503). In his opinion, for a translator of fiction, the starting point should be "the work itself as a whole, its living image that illuminates all the details" (Kashkin, 1977, p. 428). At the same time, "the translator must know the reality reflected in the original, and go there with the author from his text, and having understood the author, understand the reader, know his attitude and perception, and be able to bring the originality of the original to the reader in his translation" (Kashkin, 1977, p. 510). Thus, the translator combines the reader who directly perceives the original, then the literary critic or critic who analyzes the artistic side of the original, and, finally, the writer who creatively recreates the original. The translator of fiction must be both "true" to the original and focused on the recipient and the target culture's norms. If he ignores the linguistic picture of the world as a whole, using only its fragments, the reader as the recipient of the translated text will not get a complete impression of the work because he knows less about the reality reflected in the original than the recipient of the original. Consequently, the reader's lack of necessary background knowledge leads to the explication of implicit information.

Ideally, the translation should organize our perception around the translated book in the same way that the original organized the reader's perception around itself. One of the difficulties of translation is the transition from one language to another and from one culture to another. Therefore, the translator must not only have a good command of the two languages, the source and the translator (in contrast to the concept that has long prevailed in our Humanities, according to which the translator must be competent in the language into which he translates) but also have deep extralinguistic knowledge to help the reader-recipient of the translation avoid the difficulties of misunderstanding that arise from socio-cultural differences. In translating a work of art, the language worldview of the author and the translator interact, resulting in a modified language worldview of the source text.

The translator's idea of the world picture of the translated text recipient is a kind of reflected reality with which the translation interacts.

The worldview of a native Spanish speaker and an author writing in Spanish is particular. As M. Kutyeva notes, "the expansive egocentrism of the Spanish national character with its ornamental metaphor and relentless play was embodied in various verbal phenomena. The opportunity to gradually get acquainted with the phenomenon of linguization of the psyche's national and cultural characteristics appears from the first attempts to plunge into the elements of a foreign language for us. Deep in the country, verbal and spiritual treasures, amazing beauty, contradictions and surprises of language, opening the oceans to its shape, reaching to the heights of literary and poetic art of magic, conquered them and submitting them, to return is impossible" (Kutyeva, 2012, p. 71).

\section{MATERIALS AND METHODS}

We believe that an in-depth analysis must consider a literary work in a specific historical setting-among its peers and predecessors. The leading approach in this work is the method of linguistic text analysis, which is based on all linguistic methods and is characterized by extreme ambiguity. In the article, linguistic analysis is combined with literary studies and is understood as a linguistic-semantic analysis focused on understanding the text's subject-logical content, factual, and conceptual information. Simultaneously, the determining factor that unites linguistic methods is the idea of the text as a unit of analysis. The method of complex text analysis used in this work includes analyzing several factors that distinguish a particular text from other types 
of text, which allows us to trace the relationship between the linguistic and extralinguistic side of the text. We also use the hermeneutical method of interpretation, which we define after A. Platas Tasende, as "ciencia de la interpretación textual mediante la que se trata desentrañar el verdadero sentido de las obras escritas" (the science of textual interpretation, which consists in understanding the true meaning of a written work) (Platas Tasende, 2007, p. 316). We consider this method suitable for analysis, since we do not aim to confirm the authenticity or falsity of the hypothesis but understand and interpret the author's text's essence. We also use the method of comparative analysis of translation, that is, analysis of the form and content of the translation text compared to the form and content of the original. These texts are objective facts that can be observed and analyzed. Individual relationships are established between two texts in different languages (the original text and the translation text). By comparing such texts, we attempt to reveal the internal translation mechanism, identify equivalent units, and detect form and content changes when the original unit is replaced by an equivalent unit of the translated text. It is also possible to compare two or more translations of the same original. Comparative analysis of translations allows us to find out how typical translation difficulties related to the specifics of the Spanish language are overcome and what elements of the original remain untranslated in translation. As a result, we get a description of the "translation facts," which gives a picture of the entire process.

\section{RESULTS AND DISCUSSION}

Obsessed with a postmodern passion for mixing styles, C. Ruiz Zafón boldly experiments with the syllable. In the fabric of all his works, romanticism and adventure, naturalism and mysticism, science fiction, and fairy tale are present in various proportions.

The method of mixing genres and styles may serve as a convenient means for the writer to create a universal psychological book about man's eternal fears and the eternal struggle with himself, to change, making mistakes, striving for perfection, but never achieving it. Like the best Latin American novels, the tetralogy has a multi-linear plot and polyphonic structure, reworks genre forms known to the world literature, and develops the plot on the principle of a labyrinth, where any surprises are possible (Pisanova, 212, $\mathrm{p}$. 202-203; Zvereva, 2016, p.141). The bold mixing of genres reveals narrative intertextuality. References to storylines, episodes, parallels already known in the world literature and unexpected twists replace each other, intersperse, there is a roll call of "fresh words and stamped words" (Zvereva, 2016, p. 154). This creates a unique author's artistic picture of the world. "The main binomial in Ruiz Zafón's short stories is the angel/demon pair, which has an extensive literary history and motivates a broad polylogue and discussion. The grounded artistic images-comparisons in the analyzed novels are saturated with the expression of significant sensory power. Before the reader appears an angel with reptilian eyes, in black clothes, with a wolf (dog) grin, animal fangs, claws, furry paws, exuding the smell of sulfur, such fruits of artistic fantasy, subjected to deliberate infantilization and stylized as adolescent perception, are a manifestation of the most important universal antitheses (light - darkness, harmony-ugliness, life-death) (Zvereva, Kutyeva, 2018, p. 247).

In the spirit of eclecticism, the writer confronts the incomparable and contradictory. His text is full of oxymorons, such as "blinding darkness," "dark light." Even at the beginning of the story, we face oxymoronic phenomena that require the translator's imagination and virtuoso skill. The hero of the novel, Daniel Sempere, lost his mother early and is deeply affected by this loss: "La ausencia de mi madre era para mí todavía un espejismo, un silencio a gritos, que aun no había aprendido a callar con palabras" (Ruiz Zafón, 2001 , p. 17). Here is a translation that is as close as possible to the original, almost literal: "the Absence of my mother did not let me go, it was an obsession for me, a screaming silence that I never learned to hush up with words" (our Translation -E. Z.) Translated by Smirnova-Temnov, the phrase took the following form: "Six years later, the absence of my mother still gaped in my heart, like a silent cry that I never learned to drown out with words" (Ruiz Zafón, 2016. p. 21). In the book of Ruiz Zafón, it was the silence, muteness that was crying. The translators decided to rearrange the adjective and noun: preference is given to silent shouting, rather than screaming dumbness. Such a permutation could be considered insignificant, although this inversion can be seen as somewhat illogical: is it necessary to drown out something silent? Besides, "silent" can be perceived as "a failed, unrecognized," whereas, for our hero, this pain cried (screamed) in him constantly.

Let us pay attention to the fact that C. Ruiz Zafón's inanimate images of buildings and palaces-symbols become full-fledged, influential characters of works, original embodiers of an artistic idea. The novelist focuses on the impression of mystery produced by the image formed by "silent" urban and landscape objects. The building adjusts to the hero's world, directs him, influences his personal development, turns into an exciting ally, an accomplice, or, on the contrary, an ardent opponent of the actions and plans of the 
characters. The city is personified and personalized, but in translation, it is often impossible to save the personification; it remains outside the framework of the urban landscape that is broadcast to the Russianspeaking reader. Thus, the metaphor of "Una brisa fresca peinaba la ciudad" (Ruiz Zafón, 2001, p. 48), literally meaning "a Fresh breeze brushed the city, "translated as "a Cool breeze swept the city" (Ruiz Zafón, 2016, p. 52). The phrase "La avenida del Tibidabo se desvanecía en un espejismo acuoso bajo cielos de plomo "(Ruiz Zafón, 2001, p. 277) in Russian sounds like "Tibidabo Avenue melted ahead like a wet Ghost under a leaden sky" (Ruiz Zafón, 2016, p. 285). Translation inevitably loses its personification: the verb's choice to melt may lead the reader to associative parallels with snow, ice, or ice cream. Russian translation of the word "personification" has disappeared due to the inability to convey the entire semantic palette of the verb desvanecerse, where along with the meanings of a wide range of action, namely: "disappear, fade, disperse," a purely "human" meaning coexists: "faint," "lose consciousness," which will not happen to "see the light" in the translation into Russian.

On each page of the novel, you can find "ethereal" words: air, atmosphere, clouds, twilight, semi-darkness, shadows, smoke, steam, haze (Ruiz Tosau Eduardo, 2008). Together, these words contribute to forming a figurative picture of the world and the life of the characters, becoming its allegory. The main character of the novel "Shadow of the wind" Clara inconsolably declares: "Este es un mundo de sombras" ("Our world is a world of shadows") (Ruiz Zafón, 2001, p. 36) and the statement of Daniel's father, which begins the day of visiting the warehouse of forgotten books, "hay cosas que sólo pueden verse entre tinieblas" ("there are things that can only be seen at dusk") (Ruiz Zafón, 2001, p. 8), represents, from our point of view for example, a reference to the novel "One hundred years of solitude" by G. Garcia Marquez, where the blind Ursula saw better than the sighted. Below is a table that compares the full statement from the original Spanish and the existing translation. Besides, the table below offers our vision of the most appropriate optimal translation from the point of view of pragmatics.

\begin{tabular}{|c|c|c|}
\hline Original & Translation by Smirnova-Temnov & Our proposed translation \\
\hline $\begin{array}{c}\text { Hay cosas que sólo pueden } \\
\text { verse entre tinieblas - insinuó mi } \\
\text { padre blandiendo una sonrisa } \\
\text { enigmática que probablemente } \\
\text { había tomado prestada de algún } \\
\text { tomo de Alejandro Dumas }\end{array}$ & $\begin{array}{c}\text { Some things are only visible at dusk, } \\
\text { my father said, smiling a soft, enigmatic } \\
\text { smile that he might have borrowed from } \\
\text { some book by Alexandre Dumas. }\end{array}$ & $\begin{array}{c}\text { Some things can only be seen at } \\
\text { dusk, - hinted (suggested) my father, } \\
\text { lighting up with a mysterious smile, as } \\
\text { if taken from some volume of } \\
\text { Alexandre Dumas. }\end{array}$ \\
\hline
\end{tabular}

Table 1.

Reading the translation, you wonder: "Where did the soft smile suddenly come from?". There is no softness in the father's smile, but there is a mystery. The "softness" of the translation was suggested by the verb blandir, because it is consonant with the adjective blando / soft, which turned out to be a "false friend" of the translator here. Phonetic parameters limit the proximity of these two lexemes in modern Spanish. Semantically, blandir and blando are different words. Suppose we turn to the Spanish-Russian dictionary of I. Martinez Calvo, we will see that blandir means 'to swing, shake, sway, flatter, please, ingratiate' (Martinez Calvo, 1997, p. 84). In other words, the father's face wavered, flickered, showed a mysterious smile, or- "a mysterious smile spread over his face."

I would also like to note the writer's commitment to certain words and phrases. Thus, the word espejismo (mirage, haze) and the phrase penumbra azulada are repeated several times in the novel. However, this repeated vocabulary is translated into Russian in different ways each time, which seems to us quite justified. So, la penumbra azulada in the Russian version is both "bluish morning light" and "bluish twilight". "Página a página, me dejé envolver por el sortilegio de la historia y su mundo hasta que el aliento del amanecer acarició mi ventana y mis ojos cansados se deslizaron por la última página. Me tendí en la penumbra azulada del alba con el libro sobre el pecho y escuché el rumor de la ciudad dormida goteando sobre los tejados salpicados de púrpura". Here is the translation of Smirnova-Temnov: "Turning page after page, I was completely at the mercy of the novel and its world, until a light pre-dawn breeze blew through my window. But now my tired eyes glanced at the last lines. In the bluish morning light, I lay on my bed with a book on my chest, listening to the dull sounds of the sleeping city, like a light morning rain rustling on purple roofs" (Ruiz Zafón, 2016, p. 29). We offer the following translation: "Page after page I was immersed in the spell of this story, in its world, and now the breath of dawn gently touched my window, and my tired gaze slid over the last page. I stretched out in the bluish haze of dawn, my book on my chest, listening to the rustle of the sleepy city, the sound of raindrops on roofs spattered with purple." We do not see the translation of the word sortilegio as "power" quite successful, because its semantics are closer to such concepts as "witchcraft, 
sorcery, enchantment, sorcery". Unmanifested was a metaphorical picture depicting how the reddish rays of the rising sun play, like splashes of living water, on the roofs of sleeping houses.

Images of buildings and palaces-symbols affect each episode's mood, sometimes even create emotions of anxiety or longing, happiness, and serenity, sometimes give the story a mystery. At the beginning of the novel, Barcelona of the 40s appears to the reader "atrapada bajo cielos de ceniza y un sol de vapor que se derramaba sobre la Rambla de Santa Mónica en una guirnalda de cobre líquido... " (Ruiz Zafón, 2001, p. 7). In the translation of Smirnova-Temnov: "we walked through the streets of Barcelona, covered (captured, trapped) with an ashen sky and a smoky sun, a garland of liquid copper spreading along the Boulevard La Rambla de Santa Monica." We think it is worth highlighting, giving the texture of the verb atrapar, translated into Russian as "to grab to catch in a trap," then the translation will become more accurate: "we were walking through the streets of Barcelona, captured by the ashen skies."

\begin{tabular}{|c|c|c|}
\hline Original & $\begin{array}{c}\text { Translation by Smirnova- } \\
\text { Temnov }\end{array}$ & Our proposed translation \\
\hline $\begin{array}{c}\text { Una penumbra azulada lo } \\
\text { cubría todo, insinuando <... } \\
\text { una galería de frescos poblados } \\
\text { con figuras de ángeles y } \\
\text { criaturas fabulosas. }\end{array}$ & $\begin{array}{c}\text { In the Palace, there was a bluish } \\
\text { semi-darkness, in which the } \\
\text { gallery, once painted with } \\
\text { frescoes depicting angels and } \\
\text { chimeras, was barely } \\
\text { discernible. }\end{array}$ & $\begin{array}{c}\text { A bluish haze spread over everything (or: } \\
\text { everything was covered with a bluish } \\
\text { haze), and in it, the outlines of a marble } \\
\text { staircase and a gallery with frescoes dotted } \\
\text { with figures of angels and fairy-tale } \\
\text { creatures were barely visible. }\end{array}$ \\
\hline $\begin{array}{c}\text { Seguimos al guardián y } \\
\text { Ilegamos a una gran sala } \\
\text { basílica de tinieblas yacía } \\
\text { bajo una cúpula acuchillada } \\
\text { por haces de luz. }\end{array}$ & $\begin{array}{c}\text { We followed our guide <...> and } \\
\text { entered a circular hall, where the } \\
\text { Church was in semi-darkness, } \\
\text { from under the dome of which } \\
\text { beams of sunlight streamed } \\
\text { through the Windows. }\end{array}$ & $\begin{array}{c}\text { We followed the guardian through the } \\
\text { Palace corridor and came to a large } \\
\text { circular hall where the real temple of } \\
\text { shadows rested under a dome pierced by } \\
\text { blades of light. }\end{array}$ \\
\hline
\end{tabular}

\section{Table 2.}

In our opinion, the Russian sentence suffers from syntax because the subordinate determinative introduced by the word "which" follows not the syntactic part to which it directly relates, but another (second) subordinate introduced by the conjunction "where." Thus, the proposal turned out to be inconsistent and difficult to understand. There is a logical failure: 1) if there are sheaves of light, why is it dark? 2) the windows mentioned in the translation are not actually in the original; 3) the author's metaphor about piercing space with "light" knives is lost in the translation; 4) the syntagma "twilight reigned" is repeated twice (at first, the twilight was bluish, and then it became ecclesiastical), which is not dictated by the original text; 5) the equivalent "guide" is inappropriate.

Phraseological units are a traditional stumbling block in translation, and many of them were ignored by translators. Modified phraseological units are particularly difficult. Thus, in the novel, the phrase "no está el horno para bollos" (literally: "the oven is not ready for buns") appears in a creative and contextually determined variation of "no está el horno para flores" (the oven is not ready for flowers): "Le quise vender un clavel para el ojal y me envio a la mierda, diciendo que habia una guerra y que no estaba el horno para flores" (Ruiz Zafón, 2001, p. 117). Although there was no equivalent for phraseology in Russian, the translators got out of the situation with honor, somewhat softening the obscene connotation and focusing on the communicative pragmatics of the statement: "I offered him to buy a carnation for his buttonhole, and he told me to shove it. To hell with flowers when there is a war going on!" (Ruiz Zafón, 2016, p. 121).

Besides, the translation authors rephrased the original "I wanted to sell him a clove" to "I offered to buy it." This transformation seems acceptable to us. Nevertheless, let us emphasize that the concept of "selling" plays a massive role in the perception of the world by Europeans- a role that is not comparable to the importance of the phenomenon of "sell" for Russians. In this regard, we fully agree with the conclusions drawn by L. Moiseenko in the course of her comparative research, who believes that some concepts that are relevant for one culture may not be relevant for another. Then when translated, "they are translated only in the status of a "concept-minimum" due to the impossibility of transmitting the entire semantic palette embodying an alien concept sphere" (Moiseenko, 2015, p. 188).

Since the dialogues in the novel "Shadow of the wind " contain many phraseological units, are lively and natural, the translation ship is continuously at risk of crashing on their reefs. The situation is further 
complicated because C. Ruiz Zafón experiments on the idiomatic field, cutting down phraseological combinations, proverbs, and sayings, and modifying and varying them (Calle Rosingana Gonçal, 2014). For a native Spanish speaker, the context and precedent usage are sufficient for the transformed idiom's semantic and connotative preservation. The meaning will not always be transparent to the reader or even a professional translator, for whom Spanish is not their native language.

\begin{tabular}{|c|c|c|}
\hline Original & Translation by Smirnova-Temnov & Our proposed translation \\
\hline $\begin{array}{c}\text { 1)- Esta noche usted y yo nos vamos } \\
\text { de picos pardos a un local de la calle } \\
\text { Platería que al parecer está } \\
\text { causando furor. Me han dicho que } \\
\text { hay unas fámulas nórdicas recién } \\
\text { llegadas de Ciudad Real que le } \\
\text { quitan a uno hasta la caspa. Yo } \\
\text { invito. } \\
\text { 2)- ¿Y la Bernarda qué dirá? } \\
\text { - Las niñas son para usted. Yo } \\
\text { pienso esperar en la salita, leyendo } \\
\text { una revista y contemplando el percal } \\
\text { de lejos, porque me he convertido a } \\
\text { la monogamia, si no in mentis al } \\
\text { menos de facto. }\end{array}$ & $\begin{array}{c}\text { - Tonight we're going on a wild night } \\
\text { out at an impressive place on Plateria } \\
\text { street, where I'm told there are some } \\
\text { amazing Northern girls, fresh from } \\
\text { Ciudad Real, who strip all the way to } \\
\text { the scalp. My treat. } \\
\text { "What will Bernarda say?" } \\
\text { - Girls for you, and I'll sit in the hall, } \\
\text { read the newspaper, admire from afar. I } \\
\text { now adhere to monogamy, if not } \\
\text { spiritually, at least in fact. }\end{array}$ & $\begin{array}{l}\text { - And you, Bernarda, - what } \\
\text { would you say? } \\
\text { "The girls are yours. I'll wait, read } \\
\text { a magazine, watch the whole } \\
\text { thing from a distance because } \\
\text { now I have turned to monogamy, } \\
\text { if not in my mind, then at least de } \\
\text { facto. }\end{array}$ \\
\hline
\end{tabular}

Table 3.

When analyzing the translation, we had the following comments:

1 ) it is not clear why it was necessary to change the magazine to a newspaper.

2) the word "percal" remains untranslated.

3) the word "spiritual" is inappropriate. It would be better to replace it with "in mind."

One sentence contains three phraseological units: "ir de picos pardos", "causar furor"and "quitarle a uno hasta la caspa". "Quitar la caspa" seems to have been misinterpreted by the authors of the official translation. This phraseology, which is derived from "quitar el hipo," literally means "remove hiccups, get rid of hiccups," which, as you know, is quite challenging to do. Metaphorically, it translates as "stun," "greatly surprise," "make you numb." The eerie translation of this idiom as "stripping to the scalp" raises doubts and objections. We suggest describing the girls from the North as "breathtaking." You can give one of the Russian phraseological units "they give you goosebumps," "they make your hair stand on end."

Besides, there are a lot of stylistic mistakes in translation. Thus, the phrase "the lightning flash highlighted the smoke rings that hovered in the air like garlands of steam" (Ruiz Zafón, 2016, p. 128) is a tautology: "soar - steam" (in Russian «парить - пар»). Such carelessness is due to haste, the need to meet the deadline. In general, the entire phrase can be interpreted at least as a semantically inconsistent construction. "Garlands of steam" is a metaphor of dubious artistic quality.

\section{CONCLUSION}

In the twenty-first century, we can talk about a particular type of reader - a reader-researcher, who, in turn, needs a new type of translator, who not only understands the meanings of words, concepts and realities of reality, but also the concepts that make up the specifics of a particular culture. In this case, a select type of interpretation of the text - the commentary of a work of fiction-comes to the fore of a translator of fiction's professional activity. It avoids semantic losses in translation and contributes to a deeper understanding of the text by the translation reader. $V$. Karasik defines translation commentary as "a genre of hermeneutical discourse" that "represents a secondary textual formation and serves as an explanation, confirmation, clarification, and critical evaluation of the information contained in the source text" (Karasik, 210, p. 237). Defining for modern literary translation is the requirement of the most careful attitude to the object of translation and its reconstruction as a work of art in the unity of content and form, in national and individual identity. The translation is not limited to transcoding, but it is also an explanation and interpretation. The translation competence also includes elements of two cultures that come into contact in the translation 
process. Thus, when faced with the peculiarities of two cultures, the translator must clearly understand their differences and convey information as accurately as possible from the carrier of one culture to the carrier of another. In our view, the novel "Shadow of the Wind" by C. Ruiz Zafón deserves a more thoughtful attitude, and the existing Russian translation can and should significantly be reworked from the point of view of selecting semantically and stylistically more adequate lexical and phraseological means.

\section{ACKNOWLEDGMENT}

This paper has been supported by the RUDN University Strategic Academic Leadership Program.

\section{REFERENCE LIST}

Babenko, L. G. (2005). Linguistic analysis of a literary text. Theory and practice: textbook; practicum. Moscow.

Calle Rosingana Gonçal. (2014). Activación de expresiones idiomáticas incompletas y prominencia semántica. Retrieved from http://cvc.cervantes.es/lengua/paremia/pdf/022/014_leal.pdf

Ilina, L. E. (2016). Magic realism as a distinctive feature of Latin American literature.

Materials of the all-Russian scientific and methodological conference "University complex as a regional center of education, science, and culture." Orenburg: Orgu Publishing House, pp. 2025-2027.

Karasik, V. I. (2010). Language crystallization of meaning. Moscow.

Kashkin, I. A. (1977). For the reader-contemporary. Moscow.

Kutyeva, M. V. (2012). Features of the Spanish national character: their trace in the "first hundred" Spanish words. Bulletin of the Vyatka State University for the Humanities, N.2-2: 64-72.

Larikova, Yu. (2018). The Literary myth of Facundo Quiroga in the cultural picture of the world of Argentines. Observatory of culture, 15 (2): 238-244.

Martinez Calvo, L. (1977). El Gran Diccionario Español-Ruso. ISBN-10: 5-88400-004-9

Moiseenko, L. V. (2015). Ethno-Cultural content of the concept and its reflection in translation. Russian language and literature in the space of world culture. Materials of the XIII MAPRYAL Congress. Pp. 188-192.

Pimenova, M. V. (2014). Language picture of the world. Moscow.

Pisanova, T. V. (2012). Inter-Genre game in the new Latin American novel. Vestnik of MSLU, 19 (652): 194205.

Platas, Tasende, A. M. (2007). Diccionario de términos literarios. Madrid: Espasa Calpe.

Ruiz Tosau Eduardo. (2008). Algunas consideraciones sobre "La sombra del viento de Ruiz Zafón". Revista de estudios literarios, 38. Madrid. Espéculo. Retrived from https://pendientedemigracion.ucm.es/info/especulo/numero38/soviento.html

Ruiz Zafón, C. (2001). La sombra del viento. Barcelona: Ed. Planeta.

Ruiz Zafón, C. (2016). Shadow of the wind. M.: AST. (in Russian). Retrieved from http://knijky.ru/books/tenvetra

Sadokhin, A. P. (2014). Introduction to the theory of intercultural communication. Moscow.

Toper, P. M. (2001). Translation in the system of comparative literature. Moscow.

Zvereva, E. V. (2016). The genius of the labyrinth or the labyrinth of genius: some features of the literary style of Carlos Ruiz Safon. Ancient and New Romania, 18: 141-155. Retrieved from https://elibrary.ru/download/elibrary_28286207_69239327.pdf

Zvereva, E. V., Kutyeva, M. V. (2018). The Spanish neo-Gothic novel as a didactic resource (based on the material of the short stories of C. Ruiz Zafón). In: Education. The science. Scientific personnel, 3: 247250. Moscow: UNITY-DANA. Retrieved from https://elibrary.ru/item.asp?id=35671542. 